\title{
Antiproliferative Effect and Apoptosis Induced in Human Cell Lines by Bruguiera gymnorhiza Barks Methanol Extract
}

\author{
Warsinah $^{1 *}$, Sismindari ${ }^{2}$, Ratna Asmah Susidarti ${ }^{2}$ \\ ${ }^{1}$ Department Pharmacy, Faculty of Medicine and Health Sciences, Universitas Jendral Soedirman, Purwokerto \\ ${ }^{2}$ Faculty of Pharmacy, Gadjah Mada Univesity, Yogyakarta
}

\begin{abstract}
The Antiproliferative effects of methanol extract from Bruguiera gymnorhiza (B. gymnorhiza) barks were tested in vitro against three human cell lines: Hela, Raji and Myeloma cells. The extract was found to have antiproliferative effects against Hela, Raji and Myeloma cells with an $\mathrm{IC}_{50}$ value of 133, 504 and $384 \mu \mathrm{g} / \mathrm{mL}$, respectively. The antiproliferative test was then performed on Hela, Raji, and Myeloma cells. Cytotoxicity assay of the extract was then determined using MTT method. There were some indications of apoptosis, such DNA fragmentation, as assessed by acrydine orange- ethidium bromide staining. These results indicate that extract from $B$. gymnorhiza barks can induce apoptosis in human cell lines.
\end{abstract}

Keywords: Antiproliferative, Apoptosis, B. gymnorhiza

\section{INTRODUCTION}

Apoptosis is widely observed in various cells of most organisms, from nematodes to mammals, and it is generally accepted to play an important role in the physiological processes during maturation of the immune system, embryogenesis, metamorphosis, endocrinedependent tissue atrophy, and normal tissue turnover (Willye et al, 1980). Furthermore, apoptosis is induced in various cell lines in vitro by incubating the cells with chemicals such as and tumor agent (Tsuruo et al, 2003). Apoptosis is a unique morphological type of cell death that is characterized by chromatin condensation (Cohen, 1993).

Apoptosis plays a crucial role in the regulation of tissue homeostasis. Many studies have indicated that an imbalance between cell death and cell proliferation may result in tumor formation. The killing of tumor cells can be acquired through diverse catatonic approaches, such as anticancer drugs, gamma - irradiation or immunotherapy, which are predominantly mediated through the induction of apoptosis (Pasechnik et al, 2000).

Bruguiera gymnorhiza is a family of rhizoporaceae, a mangrove plant. Many Indonesian people use the leaf and stem bark of the plant as antimicrobial, antifungal, antivirus, anticancer, insecticide and antileukemia (Soetarno, 2000). The research on the effect of B. gymnorhiza's stem bark ethanolic extract was reported to be cytotoxic towards myeloma and raji cell lines with $\mathrm{IC}_{50}$ $301.78 \mu \mathrm{g} / \mathrm{mL}$ and $582 \mu \mathrm{g} / \mathrm{mL}$ (Warsinah, 2005). Stem bark of $B$. gymnorhiza exhibited antimicrobial activity against Aeromonas sobria, Pseudomonas stutzeri dan Vibrio parahaemolyticus of udang windu (Chen, et al., 2007). A chemical compound isolated through fermentation of $B$. gymnorrhiza roots with peniccilium thomi resulted in the finding of 12 compounds: 4',5- dihydroxi -2-3- dimethoxy -4(hydroxipropyl)-biphenyl (1) and 11 other compounds with cytotoxic effect to 3 cancer cells (A549,HepG2 dan HT29). Homhual et al (1996), isolated sulfuric compounds from the flowers of $B$. gymnorrhiza, namely cyclic 4- hidroxydithiosulfonat (bruguisulfurol), hidroxydithiolane 1-oxida (bruguierol) and isobruguierol.

*Corresponding author e-mail : warsinah@ rocketmail.com 


\section{MATERIALS AND METHODS}

\section{Chemicals}

Medium RPMI (RPMI 1640 (Sigma), sodium bicarbonat (Sigma) dan Hepes (Sigma)), fetal bovin serum (FBS) (Gibco) 10\% (v/v), penicillin-steptomycin (Gibco) $1 \% \quad(\mathrm{v} / \mathrm{v})$, fungizone (Gibco) 0,5\% (v/v), sterile aquadest, ethanol $96 \% \mathrm{v} / \mathrm{v}$, DMSO, Acridine Orange, etidium bromida, ethanol 70\% (E Merck), Sodium Dodecyl Sulfat (SDS) $10 \%$ in $\mathrm{HCl}$ ), Silica gel GF 254 , MTT (3- $(4,5-$ dimethylthyazole),2,5, diphenyltetrazolium bromide) $5 \mathrm{mg} / \mathrm{mL}$ in FBS, Asetic acid glacial (E Merck), Amonia (E Merck), methanol, chloroform, $n$-hexane, ethyl acetate.

\section{Cell line and culture Condition}

The cell lines used in this study were Hela, Raji and Myeloma cell, which were provided by the Parasitology Laboratory of Faculty of Medicine Gadjah Mada University. Hela, Raji and Myeloma cell lines were cultured in RPMI 1640 medium suplemented with $10 \%$ fetal bovin serum at $37^{\circ} \mathrm{C}$ in $5 \% \mathrm{CO}_{2}$.

\section{Extraction of stem bark}

Five hundred grams of stem bark powder was macerated with $3 \mathrm{~L}$ of methanol for $3 \times 24 \mathrm{hrs}$. The filtrate was evaporated with rotary evaporator, residue of the methanol extract obtained was 53.6 gram.

\section{Preparation of Test Solution}

Methanol extracts of $20 \mathrm{mg}$ was weighed and dissolved in $100 \mathrm{~mL}$ DMSO. Then a series of extract concentration in RPMI medium 1640 was made into the treatment stock solution. A total of $20 \mathrm{~mL}$ of stock solution dissolved in RPMI medium to obtain concentrations of $1000 \mu \mathrm{g} / \mathrm{mL}$, further diluted to concentrations of 500, 250, 125 and $62.5 \mu \mathrm{g} / \mathrm{mL}$. Preparation of test solution was performed in a laminar air flow cabinet aseptically.

\section{Antiproliferative effect with MTT methods}

Three cell lines, Hela, Raji and Myeloma cell were used for cytotoxicity and antiproliferative assay. Near-confluent cells were collected and diluted to a concentration of $2 \times 10^{4}$ cells $/ \mathrm{mL}$ with culture medium. One hundred microliter aliquot of cell suspension were dispensed into each well of 96- well plate. The residue from extract stem bark B. gymnorhiza was redisolved in DMSO. The treatment concentrations were $1000,500,250,125$ and $62,5 \mu \mathrm{g} /$. After $24 \mathrm{hrs}$ of incubation at $37^{\circ} \mathrm{C}$ in $5 \% \mathrm{CO}_{2}$, each well was treated with doxorubicin at concentrations of $0.2,0.1,0.05,0.025$ and 0.0125 $\mathrm{mg} / \mathrm{mL}$ and control of $100 \mu \mathrm{l}$ suspension cell in medium. It was then incubated at $37^{\circ} \mathrm{C}$ of $24 \mathrm{hrs}$. In each well $10 \mu \mathrm{l}$ of MTT $5 \mathrm{mg} / \mathrm{mL}$ in RPMI was added followed by $4 \mathrm{hrs}$ of incubation at $7^{\circ} \mathrm{C}$. The reaction was then stopped with SDS. After incubation for $24 \mathrm{hrs}$ the absorbance of each well was measured $595 \mathrm{~nm}$ using Elisa reader.

\section{Detection of apoptosis Induction}

Apoptosis of the cells were detected by ethidium bromide-acrydine orange. Near-confluent cells were collected and diluted to a concentration $3 \times 10^{4} / 100$ cells $/ \mathrm{mL}$. One hundred microliter aliquots of cell suspension were distributed on cover slips in a 24-well plate. The extract was dissolved in DMSO and was diluted to 30, 15 and $7.5 \mu \mathrm{L}$. The extract was then used to treat the cells. Then the plate was incubated for 24 hours. The cells were then observed by flourescence microscope after adding ethidium bromideacridine orange to the cover slips .

\section{RESULTS AND DISCUSSION}

Initially, we examined the antiproliferative effects of the extract obtained from the stem bark of $B$. gymnorhiza in human cancer cell lines. The extract showed antiproliferative effects towards HeLa, Raji and Myeloma cell in this study, with an $\mathrm{IC}_{50}$ value of 133,504 and $384 \mu \mathrm{g} / \mathrm{mL}$, respectively.

To investigate its antiproliferative activity further, the methanol extract from $B$. gymnorhiza was subjected to cell antiproliferation assay using HeLa, Raji and Myeloma cells. HeLa, Raji and Myeloma cells were treated with the stem bark $B$. gymnorhiza extract $(75 \mu \mathrm{g} / \mathrm{mL})$, and cell proliferation was examined at intervals by MTT assay. As shown in Fig. 1. The proliferation of the cells increased in time-dependent manner. Similar to the control.

The difference in cell number between the control and treated with tested extract metanol at any time were analyzed by LSD test with an error rate of $5 \%$. The results of the analysis presented in Table I. Morphological changes in the cell caused by the extract methanol of stem bark $B$. gymnorhiza were observed by microscopy, as shown in Fig. 2. After 1-hrs incubation with the stem bark extract, the HeLa cells had swelled in comparison to the control cells (Fig.2, Extract 1 hour and control 1 hour). After 24 hours, dead cells were observed among the treated cells.

Next, the Hela cells were exposed to 133 $\mu \mathrm{g} / \mathrm{mL}$ of extract for $24 \mathrm{hrs}$ and the occurence of 
apoptosis was observed. This result comfirm that methanol extract of stem bark B.gymnorhiza can

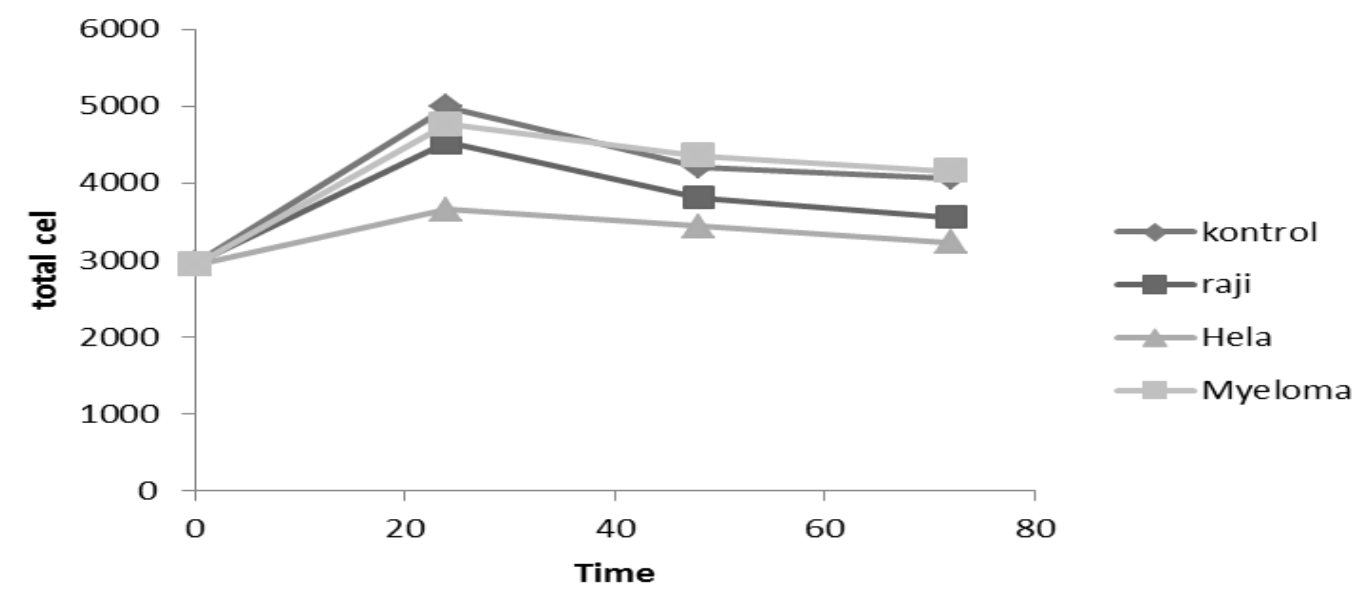

Figure I. Cell proliferation (absorbance) by the extract methanol from stem bark of B. gymnorhiza.

Table I. Antiproliferative test results on the cells Raji, Hela, Meyloma and control of methanol extract at different times.

\begin{tabular}{|c|c|c|c|c|c|}
\hline Time & Control & Raji & Hela & Meyloma \\
\hline 0 & $2953.3 \pm 72.3 \mathrm{a}$ & $2950.0 \pm 69.3 \mathrm{a}$ & $2940.0 \pm 62 . \mathrm{a}$ & $2940.0 \pm 62.5 \mathrm{a}$ \\
24 & $4991.3 \pm 121 . \mathrm{a}$ & $4529.7 \pm 113.5 \mathrm{a}$ & $3655.3 \pm 60.3 \mathrm{a}$ & $4759.3 \pm 150.4 \mathrm{ab}$ \\
48 & $4209.7 \pm 29.0 \mathrm{a}$ & $3807.0 \pm 67.09 \mathrm{a}$ & $3441.7 \pm 60.3 \mathrm{a}$ & $4357.0 \pm 47.6 \mathrm{a}$ \\
72 & $4064.7 \pm 105.1 \mathrm{a}$ & $3559.3 \pm 103.4 \mathrm{a}$ & $3233.3 \pm 130.5 \mathrm{ab}$ & $4157.7 \pm 90.9 \mathrm{a}$ \\
\end{tabular}

Description: Different superscript in the same column indicate significant differences $(P<0.05)$

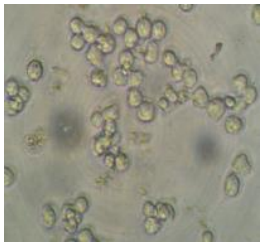

A

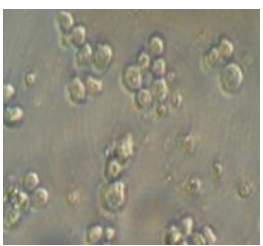

E

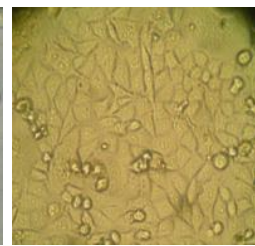

$\mathbf{B}$

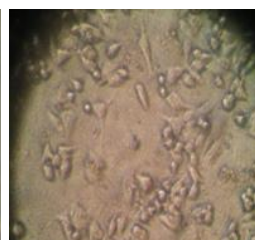

$\mathbf{F}$

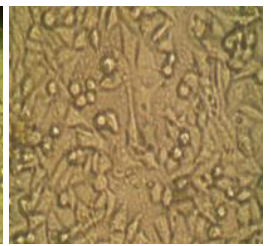

C

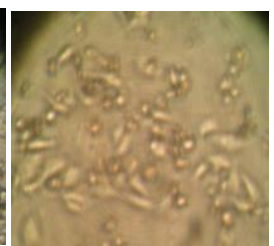

$\mathbf{G}$

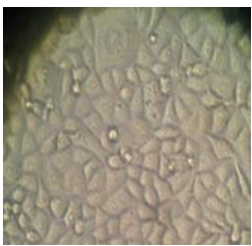

D

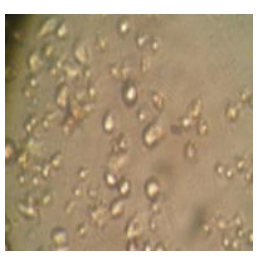

$\mathbf{H}$

Figure 2. Morphological change in HeLa cells incubated with extract methanol (A) Control 0 hours (B) Control 24 Hours (C) Control 42 hours (D) Control 72 hour (E) Extract 0 hours (F) Extract 24 hours (G) Extract 48 hours (H) Extract 72 hours. 

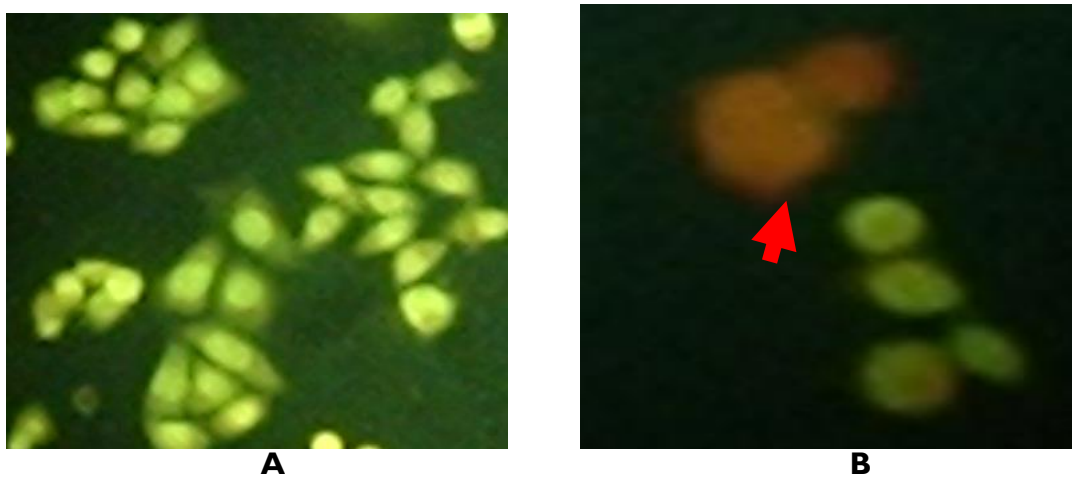

Figure 3. The result of apoptosis induction Cells by ethidium bromide-acridine orange exhibited the occurance of apoptotic cells, indicated by red $(\rightarrow$ ) arrows. (A) Control cell (B) Cell and extract

Previously we found that the ethanolic extract of B. gymnorhiza were cytotoxic towards Myeloma and raji cells line with $\mathrm{IC}_{50}$ of 301,78 $\mu \mathrm{g} / \mathrm{mL}$ and $582 \mu \mathrm{g} / \mathrm{mL}$ (Warsinah, 2005). Mimaki et al (1996) have shown that the saponins isolated from $C$. Comusum have inhibitory activity of Hela Cells as primary screening test to identification on new antitumor promoter compounds. $B$ gymnorhiza has been traditionally used as a folk medicine for cough in china (Jiang, 1977).

In the present study, we have shown that methanol extract from the stem barks of $B$ gymnorhiza has antiproliferative activity on HeLa, Raji and Myeloma cells in MTT assay. The $\mathrm{IC}_{50}$ value of the methanol extract in HeLa, Raji and Myeloma cells were between $150 \mu \mathrm{g} / \mathrm{mL}$ and did not vary much among the cell lines.

To confirm these effects by biochemical analysis, the effects of the methanolic extract was evaluated using HeLa cells. The antiproliferative activity of the methanol extract toward HeLa cells increased in a time dependent manner, as did the activity of the negative control cells. Examination of the morphology changes in HeLa cells treated with the extract showed that the cells swelled into circular form $1 \mathrm{hrs}$, and then died without fragmentation after $72 \mathrm{hrs}$, which differed from the effect of the negative control (Fig 2). These results suggest that the methanol extract of stem barks of B. gymnorhiza contains antiproliferative materials that kill HeLa cells.

To invesigate the relationship between the antiproliferative activity and apoptosis inducing activity of the methanol extract analysis by double staining (etidium bromide-acridine orange). The presence of DNA fragments indicates that the HeLa cells had undergone apoptotis. Detection of apoptotis using microscope flourescense futher indicate that methanol extract also induced apoptosis in Hella cells. Thus, these results show that the antiproliferative activity of the extract was due to induction of apoptosis.

In summary, the methanolic extract from stem barks of $B$. gymnorhiza induces difinite apoptosis in various human cells lines.

\section{CONCLUSION}

The ethanolic of B. Gymnorhiza stem bark is cytotoxic towards Hela, Raji, and Myeloma cells but the molecular mechanism of action must be studied futher to provide a more conclusive evidence.

\section{REFERENCES}

Jiang, S., 1977, Dictionary of traditional Chenese Crude drugs, vol 2, shanghai Scientific Technologic, shanghai.

McKoney, D.j., Orrenius, S. and Jondal, M., 1990, Agent that elevate c AMP Stimulate DNA frgmentation in thymocytes, J. Immunol., I45, I227-1230.

Mimaki, Y., Kanoto, T. and Ashida, Y., 1996, Steroidal saponins from underground parts of chloorophytum comusum and inhibitory activity on tumor promoter induce phospolipids metabolism of HeLa cells, Phytocemistry, 4I, I495-14II0.

Pasechnik, V., 2000, Microbial pathogens and apoptotics andicancer therapy, Expert, Opin. Investig. Drugs, 9, I243-I 256.

Tsuruo, T., Naito, M. and Tomida, A., 2003, Molecular targeting Therapy of cancer; drug resistance, apoptosis and survival signal

Warsinah, Lestari, P. and Trisnowati, 2005, Isolasi Senyawa Bioaktif pada Kulit Batang B. gymnorhiza Sebagai Bahan Andikanker. Laporan Penelitian Dasar. 
Warsinah, et al., 2011

Indones. J. Cancer Chemoprevent., 2(3), 299-303

Willy, A.H., Kerr, J.F., and Currie, 1980, Cell death; the significance of apoptosis, Int. Rev

Cytol., 68, 25I-306. 